\title{
Synthesis of New Polymer Ionomers via Ring-Opening Metathesis Polymerization
}

\author{
A. A. Santiago ${ }^{1}$, J. Vargas ${ }^{2}$, Jorge A. Cruz-Morales ${ }^{1}$, M. A. Tlenkopatchev ${ }^{1}$, R. Gaviño ${ }^{3}$, \\ Yu. A. Malkanduev ${ }^{4}$, N. A. Sivov 5 \\ ${ }^{1}$ Instituto de Investigaciones en Materiales, Universidad Nacional Autónoma de México, Coyoacán, México \\ ${ }^{2}$ Facultad de Ingeniería, Universidad Autónoma del Carmen, Ciudad del Carmen, México \\ ${ }^{3}$ Instituto de Química, Universidad Nacional Autónoma de México, Coyoacán, México \\ ${ }^{4}$ Kabardino-Balkarian State University, Nalchik, Russian Federation \\ ${ }^{5}$ A.V. Topchiev Institute of Petrochemical Synthesis, Leninsky Prospect 29, Moscow, Russia \\ Email: sivov@ips.ac.ru
}

Received 29 August 2014; revised 25 Septemner 2014; accepted 20 October 2014

Copyright (C) 2014 by authors and Scientific Research Publishing Inc.

This work is licensed under the Creative Commons Attribution International License (CC BY).

http://creativecommons.org/licenses/by/4.0/

c) (i) Open Access

\begin{abstract}
The $N$-pentafluorophenyl-exo-endo-norbornene-5,6-dicarboximide (2a) and $N$-phenyl-exo-endo-norbornene-5,6-dicarboximide ( $2 \mathrm{~b}$ ) monomers were synthesized and polymerized via ring-opening metathesis polymerization (ROMP) using bis(tricyclohexylphosphine) benzylidene ruthenium(IV) dichloride (I) and tricyclohexylphosphine [1,3-bis(2,4,6-trimethylphenyl)-4,5-dihydroimidazol-2ylidene][benzylidene] ruthenium dichloride (II). Both catalysts were used to synthesize random and block high molecular weight copolymers which were further hydrogenated using a Wilkinson's catalyst. Then, the saturated copolymers were modified by reacting with sodium 4-hydroxybenzenesulfonate dihydrate to generate new ionomers with fluoro-sulfonic acid pendant groups.
\end{abstract}

\section{Keywords}

Polynorbornene Dicarboximide, Ring-Opening Metathesis Polymerization, Ionomers

\section{Introduction}

The ring-opening metathesis polymerization (ROMP) of fluorinated norbornenes using classical metathesis catalysts is well established [1] [2]. Furthermore, the presence of fluorine containing moieties in the polynorbornene dicarboximide structures becomes important for their gas transport properties due to an increase of the interactions between the gases and the polar fluorinated moieties as well as in the free volume which in turns fa- 
cilitates the diffusion of the gas molecules through the polymer [3] [4]. The pentafluorophenyl moieties also provide the possibility of further modifications. They are highly reactive towards the nucleophilic aromatic substitutions and multiblock copolymers have been successfully prepared by a polycondensation reaction between fluorinated oligomers and hydroxyl-terminated telechelics [5].

In the present study, norbornene copolymers containing fluorinated dicarboxylic imide side moieties were prepared through ring-opening metathesis polymerization (ROMP) using bis(tricyclohexylphosphine) benzylidene ruthenium(IV) dichloride (I) and tricyclohexylphosphine [1,3-bis(2,4,6-trimethylphenyl)-4,5-dihydroimidazol2-ylidene] [benzylidene] ruthenium dichloride (II).

On the other hand, we reported the synthesis and ionic transport performance of a ionic polynorbornene dicarboximide [6] [7], therefore we have envisioned the synthesis of high molecular weight polymers, their homogenous post-hydrogenations and even further sulfonations to obtain new polymeric ionomers.

\section{Experimental Part}

\subsection{Techniques}

${ }^{1} \mathrm{H}$ NMR, ${ }^{13} \mathrm{C}$ NMR and ${ }^{19} \mathrm{~F}$ NMR spectra were recorded on a Varian spectrometer at 300,75 and $300 \mathrm{MHz}$, respectively, in deuterated chloroform $\mathrm{CDCl}_{3}, N, N$-dimethylformamide (DMF- $d_{7}$ ) and dimethylsulfoxide (DMSO$d_{6}$ ). Tetramethylsilane (TMS) and trifluoroacetic acid (TFA) were used as internal standards, respectively. Glass transition temperatures, $T_{g}$, were determined in a DSC-7 Perkin Elmer Inc., at scanning rate of $10^{\circ} \mathrm{C} / \mathrm{min}$ under nitrogen atmosphere. The samples were encapsulated in standard aluminum DSC pans. Each sample was run twice on the temperature range between $30^{\circ} \mathrm{C}$ and $300^{\circ} \mathrm{C}$ under nitrogen atmosphere. The $T_{g}$ values obtained were confirmed by TMA from the first heating cycle conducted at a rate of $10^{\circ} \mathrm{C} / \mathrm{min}$ under nitrogen atmosphere with a TA Instruments Thermomechanical Analyzer TMA 2940. Onset of decomposition temperature, $T_{d}$, was determined using thermogravimetric analysis, TGA, which was performed at a heating rate of $10^{\circ} \mathrm{C} / \mathrm{min}$ under nitrogen atmosphere with a DuPont 2100 instrument. FT-IR spectra were obtained on a Thermo Nicolet 6700 spectrometer. Molecular weights and molecular weight distributions were determined with reference to polystyrene standards on a Waters 2695 ALLIANCE GPC at $35^{\circ} \mathrm{C}$ in tetrahydrofuran using a universal column and a flow rate of $0.5 \mathrm{~mL} \cdot \mathrm{min}^{-1}$. X-ray diffraction measurements of copolymer films as cast were carried out in a Siemens D-5000 diffractometer between 4 and 70 degrees $2 \theta$, at $35 \mathrm{KV} 25 \mathrm{~mA}$, using $\mathrm{CuK}_{\alpha}$ radiation (1.54 $\AA$ ). Tapping mode atomic force microscopy (TM-AFM) was performed in air using a Scanning Probe Microscope Jeol JSPM-4210 with a NSC12 $\mu$ masch needle. The samples were imaged at ambient conditions.

\subsection{Reagents}

Norbornene-5,6-dicarboxylic anhydride (NDA) was prepared via Diels-Alder condensation of cyclopentadiene and maleic anhydride according to literature [6]. 2,3,4,5,6-Pentafluoroaniline, aniline, phenol and sodium 4-hydroxybenzenesulfonate dihydrate were purchased from Aldrich Chemical Co. and used without further purification. 1,2-Dichloroethane, dichloromethane, $p$-dioxane, toluene and $N, N$-dimethylacetamide were dried over anhydrous calcium chloride and distilled over $\mathrm{CaH}_{2}$. Bis(tricyclohexylphosphine) benzylidene ruthenium(IV) dichloride (I) and $\mathrm{ClRh}\left(\mathrm{PPh}_{3}\right)_{3}$ were purchased from Aldrich Chemical Co. and used as received.

\subsection{Synthesis and Characterization of Exo(90\%)-Endo(10\%) Monomer Mixture of $\mathrm{N}$-Pentafluorophenyl-norbornene-5,6-dicarboximide (2a)}

Monomer 2a was synthesized according to the general methodology previously described for the synthesis of aliphatic and aromatic norbornene dicarboximides [8]. Thus, 2,3,4,5,6-pentafluoroaniline reacted with NDA to the corresponding amic acid which was cyclized to imide using acetic anhydride as dehydrating agent (Scheme 1) NDA $(5.0 \mathrm{~g}, 30.5 \mathrm{mmol})$ was dissolved in $40 \mathrm{~mL}$ of $\mathrm{CH}_{2} \mathrm{Cl}_{2}$. An amount of $5.58 \mathrm{~g}(30.5 \mathrm{mmol})$ of 2,3,4,5,6- pentafluoroaniline in $20 \mathrm{~mL}$ of $\mathrm{CH}_{2} \mathrm{Cl}_{2}$ was added dropwise to the stirred solution of NDA. The mixture was boiled for $3 \mathrm{~h}$ and then cooled to room temperature. Solvent removal gave a white solid of amic acid. The obtained amic acid 1a $(10.3 \mathrm{~g}, 29.7 \mathrm{mmol})$, anhydrous sodium acetate $(2.50 \mathrm{~g}, 30.47 \mathrm{mmol})$ and acetic anhydride $(21.0 \mathrm{~g}, 205.7 \mathrm{mmol})$ were heated at $80^{\circ} \mathrm{C}$ for $24 \mathrm{~h}$. The mixture was washed with dilute $\mathrm{HCl}$ and ex-tracted into ether. The ether layer was washed with dilute $\mathrm{HCl}$, saturated $\mathrm{NaHCO}_{3}$ and $\mathrm{H}_{2} \mathrm{O}$. Solvent was evapo- 


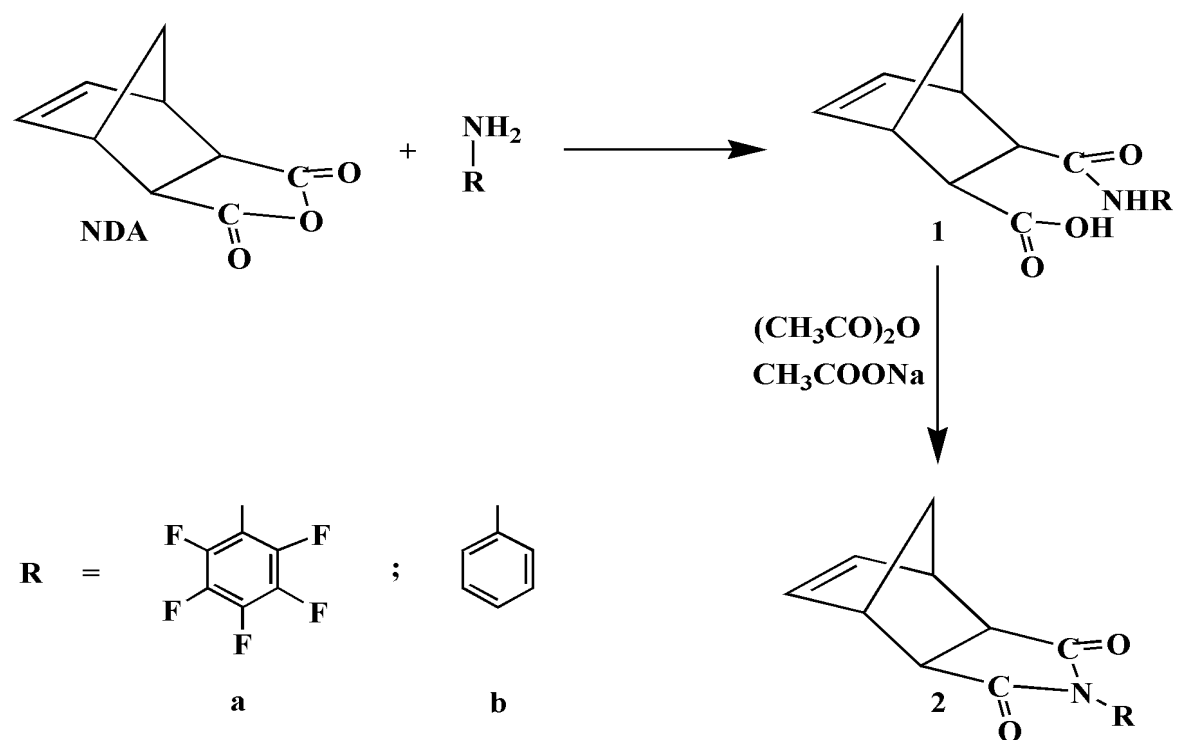

Scheme 1. Synthesis of $N$-pentafluorophenyl- and $N$-phenyl-exo-endo-norbornene-5,6-dicarboximide, 2a and $2 \mathbf{b}$, respectively.

rated and pure monomer $\mathbf{2 a}$ was obtained after twice recrystallization from hexane and dried in a vacuum oven at $50^{\circ} \mathrm{C}$ overnight: yield $=75 \%$; m.p. $=112^{\circ} \mathrm{C}-113^{\circ} \mathrm{C} ;{ }^{1} \mathrm{H}$ NMR $\left(300 \mathrm{MHz}, \mathrm{CDCl}_{3}\right), \delta(\mathrm{ppm})=6.36(1 \mathrm{H}, \mathrm{s})$, $6.25(1 \mathrm{H}, \mathrm{s}), 3.53(1 \mathrm{H}, \mathrm{s}), 3.42(1 \mathrm{H}, \mathrm{s}), 2.96(2 \mathrm{H}, \mathrm{s}), 1.70-1.54(2 \mathrm{H}, \mathrm{m}) ;{ }^{13} \mathrm{C} \mathrm{NMR}\left(75 \mathrm{MHz}, \mathrm{CDCl}_{3}\right): \delta\left(\mathrm{ppm}^{2}=\right.$ $174.7(\mathrm{C}=\mathrm{O}), 147.8$ - $139.6(\mathrm{C}-\mathrm{F}), 137.8(\mathrm{C}=\mathrm{C}), 134.4(\mathrm{C}=\mathrm{C}), 107.1(\mathrm{C}-\mathrm{N}), 52.1,48.4,45.8,45.6,42.9 ;{ }^{19} \mathrm{~F}$ NMR (300 MHz, $\mathrm{CDCl}_{3}$, ref. TFA $\left.[-77 \mathrm{ppm}]\right): \delta(\mathrm{ppm})=-142.2,-142.4,-150.1,-150.6,-160.1,-160.4$; FT-IR (KBr, cm $\left.{ }^{-1}\right): 3076,2949$ (C-H asym str), 2880 (C-H sym str), $1782(\mathrm{C}=\mathrm{O}), 1724(\mathrm{C}=\mathrm{O}), 1644(\mathrm{C}=\mathrm{C}$ str), 1519, 1356, 1299 (C-F), 1172, 1157, 984, 793.

\subsection{Synthesis and Characterization of Exo(90\%)-Endo(10\%) Monomer Mixture $N$-phenyl-norbornene-5,6-dicarboximide) (2b)}

Monomer 2b was synthesized according to literature (Scheme 1) [8] [9]. NDA (5 g, 30.5 mmol) was dissolved in $50 \mathrm{~mL}$ of toluene. An amount of $2.8 \mathrm{~g}(30.1 \mathrm{mmol})$ of aniline in $10 \mathrm{~mL}$ of toluene was added dropwise to the stirred solution of NDA. The reaction was maintained at $50^{\circ} \mathrm{C}$ for $3 \mathrm{~h}$. A precipitate was filtered and dried to give $7.6 \mathrm{~g}$ ( $29.5 \mathrm{mmol})$ of amic acid 1b. The amic acid obtained (7.6 g, $29.5 \mathrm{mmol})$, anhydrous sodium acetate $(3.0 \mathrm{~g}, 36 \mathrm{mmol})$ and acetic anhydride $(21 \mathrm{~g}, 212 \mathrm{mmol})$ were heated at $90^{\circ} \mathrm{C}$ for $6 \mathrm{~h}$ and then cooled. The solid crystallized on cooling was filtered, washed several times with water and dried in a vacuum oven at $50^{\circ} \mathrm{C}$ overnight. Pure monomer $\mathbf{2 b}$ was obtained after twice recrystallization from toluene: yield $=81 \%$; m.p. $=195^{\circ} \mathrm{C}-$ $196^{\circ} \mathrm{C} ;{ }^{1} \mathrm{H}$ NMR $\left(300 \mathrm{MHz}, \mathrm{CDCl}_{3}\right), \delta(\mathrm{ppm})=7.49-7.25(5 \mathrm{H}, \mathrm{m}), 6.33(2 \mathrm{H}, \mathrm{s}), 6.24(2 \mathrm{H}, \mathrm{s}), 3.38(2 \mathrm{H}, \mathrm{s}), 2.84$ $(2 \mathrm{H}, \mathrm{s}), 1.62-1.46(2 \mathrm{H}, \mathrm{m}) ;{ }^{13} \mathrm{C}$ NMR $\left(75 \mathrm{MHZ}, \mathrm{CDCl}_{3}\right): \delta(\mathrm{ppm})=176.8(\mathrm{C}=\mathrm{O}), 137.8(\mathrm{C}=\mathrm{C}), 134.4,131.7$ (C-N), 129.0, 128.4, 126.2, 47.7, 45,7, 42.8; FT-IR (KBr, cm $\left.{ }^{-1}\right)$ : 3064, 2946 (C-H asym str), 2877 (C-H sym str), $1770(\mathrm{C}=\mathrm{O}), 1594(\mathrm{C}=\mathrm{C}$ str), $1454(\mathrm{C}-\mathrm{N}), 1382,1329,1289,1188,975,799$.

\subsection{Metathesis Copolymerization of Monomers}

Copolymerizations were carried out in glass vials under dry nitrogen atmosphere. They were inhibited by adding a small amount of ethyl vinyl ether and the solutions were poured into an excess of methanol. The copolymers were purified by solubilization in chloroform containing a few drops of $1 \mathrm{~N} \mathrm{HCl}$ and precipitation into methanol. The obtained copolymers were dried in a vacuum oven at $40^{\circ} \mathrm{C}$ to constant weight.

\subsubsection{Synthesis of Random Poly( $N$-pentafluorophenyl-norbornene-5,6-dicarboximide-Co- $N$ - phenyl-norbornene-5,6-dicarboximide) (3)}

Monomer 2a (0.50 g, $1.51 \mathrm{mmol})$ and monomer $2 \mathbf{b}(0.36 \mathrm{~g}, 1.51 \mathrm{mmol})$ were initially dissolved in $4.34 \mathrm{~mL}$ of 
1,2-dichloroethane. Then catalyst $\mathbf{I}\left(2.49 \times 10^{-3} \mathrm{~g}, 0.0030 \mathrm{mmol}\right)$ was added and the mixture was stirred at $65^{\circ} \mathrm{C}$ for $2 \mathrm{~h}$ (Scheme 2). The obtained copolymer 3 was soluble in chloroform and dichloroethane: Incorporation of 2a in copolymer $=48 \mathrm{~mol} \% ; M_{n}=2.85 \times 10^{5} ; M_{w} / M_{n}=1.22 ; T_{g}=205^{\circ} \mathrm{C} ; T_{d}=425^{\circ} \mathrm{C} ;{ }^{1} \mathrm{H} \mathrm{NMR}(300 \mathrm{MHz}$, $\left.\mathrm{CDCl}_{3}\right): \delta(\mathrm{ppm})=7.45-7.23(5 \mathrm{H}, \mathrm{m}), 5.78(2 \mathrm{H}, \mathrm{s}$, trans $), 5.56(2 \mathrm{H}, \mathrm{s}$, cis $), 3.23-3.15(4 \mathrm{H}, \mathrm{s}), 2.87(4 \mathrm{H}, \mathrm{s})$, $2.21(2 \mathrm{H}, \mathrm{s}), 1.73(2 \mathrm{H}, \mathrm{s}) ;{ }^{13} \mathrm{C}$ NMR $\left(75 \mathrm{MHz}, \mathrm{CDCl}_{3}\right): \delta(\mathrm{ppm})=177.0(\mathrm{C}=\mathrm{O}), 174.8(\mathrm{C}=\mathrm{O}), 145.1-139.6$ (C-F), 136.2 (cis), 131.7 (trans), 129.0, 126.3, 107.2, 50.9, 46.1, 41.6; ${ }^{19} \mathrm{~F}$ NMR (300 MHz, $\mathrm{CDCl}_{3}$, ref. TFA $[-77 \mathrm{ppm}]): \delta(\mathrm{ppm})=-142.1,-142.5,-143.1,-150.0,-150.4,-159.7,-160.0$; FT-IR (thin film, $\left.\mathrm{cm}^{-1}\right): 3018$, 2923 (C-H asym str), $2853(\mathrm{C}-\mathrm{H}$ sym str), $1777(\mathrm{C}=\mathrm{O}), 1706(\mathrm{C}=\mathrm{O}), 1598(\mathrm{C}=\mathrm{C}$ str $), 1514,1455(\mathrm{C}-\mathrm{N})$, 1356, 1297 (C-F), 1165, 1139, 1066, 1021, 985, 880, 785, 768, 746, 690.

\subsubsection{Synthesis of Block Poly( $N$-pentafluorophenyl-norbornene-5,6-dicarboximide-Co- $N$ - \\ phenyl-norbornene-5,6-dicarboximide) (4)}

Monomer $2 \mathbf{b}(0.36 \mathrm{~g}, 1.51 \mathrm{mmol})$ and catalyst $\mathbf{I}\left(2.49 \times 10^{-3} \mathrm{~g}, 0.0030 \mathrm{mmol}\right)$ were stirred in $2.17 \mathrm{~mL}$ of $1,2-$ dichloroethane at $65^{\circ} \mathrm{C}$ for $0.33 \mathrm{~h}$. Then, $0.50 \mathrm{~g}(1.51 \mathrm{mmol})$ of monomer $2 \mathrm{a}$ dissolved in $2.17 \mathrm{~mL}$ of 1,2 - dichloroethane was added to the polymer solution and stirred at $65^{\circ} \mathrm{C}$ for $0.66 \mathrm{~h}$ (Scheme 2). The obtained copolymer 4 was soluble in chloroform and dichloroethane: Incorporation of $2 \mathbf{a}$ in copolymer $=32 \mathrm{~mol} \% ; M_{n}=$ $2.60 \times 10^{5} ; M_{w} / M_{n}=1.15 ; T_{g 1}=170^{\circ} \mathrm{C} ; T_{g 2}=224^{\circ} \mathrm{C} ; T_{d}=424^{\circ} \mathrm{C} ;{ }^{1} \mathrm{H}$ NMR $\left(300 \mathrm{MHz}, \mathrm{CDCl}_{3}\right): \delta(\mathrm{ppm})=7.44-$ $7.24(5 \mathrm{H}, \mathrm{m}), 5.77(2 \mathrm{H}, \mathrm{s}$, trans $), 5.55(2 \mathrm{H}, \mathrm{s}, c i s), 3.25-3.14(4 \mathrm{H}, \mathrm{s}), 2.87(4 \mathrm{H}, \mathrm{s}), 2.20(2 \mathrm{H}, \mathrm{s}), 1.68(2 \mathrm{H}, \mathrm{s})$; ${ }^{13} \mathrm{C}$ NMR $\left(75 \mathrm{MHz}, \mathrm{CDCl}_{3}\right): \delta(\mathrm{ppm})=177.1(\mathrm{C}=\mathrm{O}), 174.7(\mathrm{C}=\mathrm{O}), 144.9-139.4(\mathrm{C}-\mathrm{F}), 132.1($ cis $), 131.9$ (trans), 129.0, 126.6, $107.5(\mathrm{C}-\mathrm{N}), 50.9,46.1,41.7 ;{ }^{19} \mathrm{~F} \mathrm{NMR}$ (300 MHz, $\mathrm{CDCl}_{3}$, ref. TFA [-77ppm]): $\delta(\mathrm{ppm})$ $=-142.2,-142.7,-143.2,-150.0,-150.3,-159.7,-160.0,-160.7$; FT-IR (thin film, $\left.\mathrm{cm}^{-1}\right): 3022,2925(\mathrm{C}-\mathrm{H}$ asym str), 2838 (C-H sym str), $1774(\mathrm{C}=\mathrm{O}), 1707(\mathrm{C}=\mathrm{O}), 1588(\mathrm{C}=\mathrm{C}$ str), 1517, $1455(\mathrm{C}-\mathrm{N}), 1360,1299(\mathrm{C}-\mathrm{F})$, $1167,1022,988,746,690$.

\subsection{Hydrogenation of Block poly $(N$-pentafluorophenyl-norbornene-5,6-dicarboximide- $\mathrm{Co}-\mathrm{N}$-phenyl-norbornene-5,6-dicarboximide) (5)}

$0.5 \mathrm{~g}$ of 4 was added to $60 \mathrm{~mL}$ of solvent (dichloromethane-p-dioxane, 1:1) in a Schlenk tube. The catalyst (5 $\mathrm{wt} \%)$ was previously introduced into a Parr shaker reactor. The solution was degassed and charged into the reactor under $\mathrm{N}_{2}$. Then hydrogen was added. A $99 \%$ of hydrogenation, determined by ${ }^{1} \mathrm{H}$ NMR, for $\mathbf{5}$ was

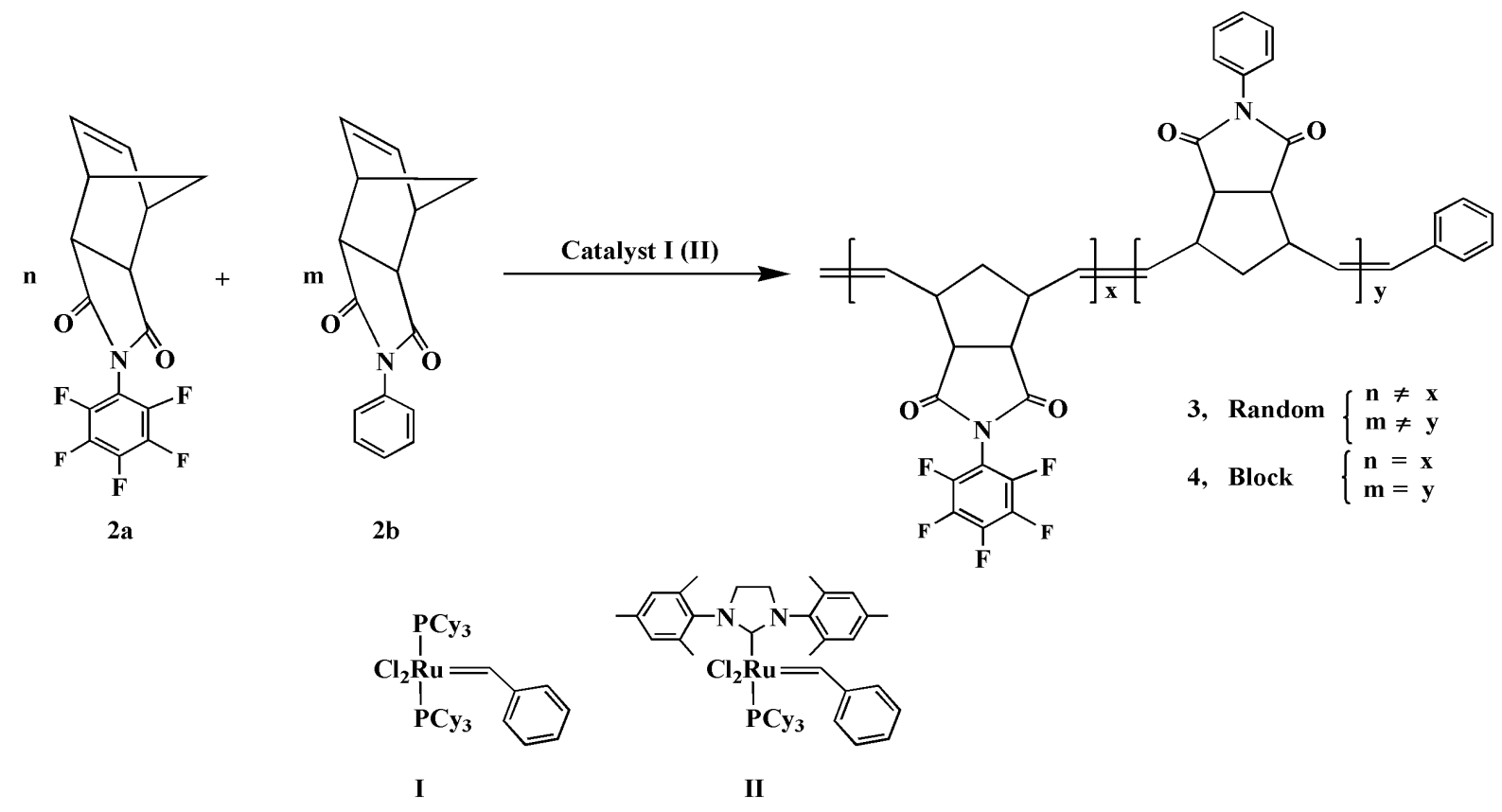


achieved using a Wilkinson's catalyst, $\mathrm{ClRh}\left(\mathrm{PPh}_{3}\right)_{3}$, at room temperature and 115 bar (Scheme 3). The obtained polymer 5 was soluble in chloroform and dichloromethane. $T_{g 1}=143^{\circ} \mathrm{C} ; T_{g 2}=198^{\circ} \mathrm{C} ; T_{d}=460^{\circ} \mathrm{C} ;{ }^{1} \mathrm{H} \mathrm{NMR}(300$ $\left.\mathrm{MHz}, \mathrm{CDCl}_{3}\right): \delta(\mathrm{ppm})=7.48-7.23(5 \mathrm{H}, \mathrm{m}), 3.03-2.93(2 \mathrm{H}, \mathrm{m}), 2.17,1.89,1.60,1.23 ;{ }^{13} \mathrm{C} \mathrm{NMR}(75 \mathrm{MHZ}$, $\left.\mathrm{CDCl}_{3}\right): \delta(\mathrm{ppm})=177.9(\mathrm{C}=\mathrm{O}), 175.6(\mathrm{C}=\mathrm{O}), 144.7-139.1(\mathrm{C}-\mathrm{F}), 131.8,128.9,128.3,126.4,107.4(\mathrm{C}-\mathrm{N})$, 51.9, 44.0, 42.1, 33.7; ${ }^{19} \mathrm{~F}$ NMR (300 MHz, $\mathrm{CDCl}_{3}$, ref. TFA $\left.[-77 \mathrm{ppm}]\right): \delta(\mathrm{ppm})=-142.2,-143.1,-150.2$, $-150.3,-159.8,-160.2$; FT-IR (thin film, $\mathrm{cm}^{-1}$ ): 2923 (C-H asym str), 2846 (C-H sym str), 1779 (C = O), 1706 $(\mathrm{C}=\mathrm{O}), 1517,1456(\mathrm{C}-\mathrm{N}), 1359,1299,(\mathrm{C}-\mathrm{F}), 1168,1036,988$.

\subsection{Sulfonation of Hydrogenated block poly( $N$-pentafluorophenyl-norbornene-5,6- dicarboximide-Co- $N$-phenyl-norbornene-5,6-dicarboximide) (6)}

Hydrogenated poly $(N$-pentafluorophenyl-exo-endo-norbornene-5,6-dicarboximide-co- $N$-phenyl-exo-endo-norbornene5,6-dicarboximide) (5) (1.0 g, $1.74 \mathrm{mmol})$, sodium 4-hydroxybenzenesulfonate dihydrate $(0.61 \mathrm{~g}, 2.62 \mathrm{mmol})$ and potassium carbonate $(0.44 \mathrm{~g}, 3.18 \mathrm{mmol})$ were mixed in a round flask equipped with a Dean-Stark trap and stirred in $22 \mathrm{~mL}$ of solvent $\left(N, N\right.$-dimethylacetamide-toluene, 10:1) at $120^{\circ} \mathrm{C}$ for $5 \mathrm{~h}$ (Scheme 3). Progressive precipitation overtime was observed. The product was then filtered off, washed several times with distilled water and dried in a vacuum oven at $40^{\circ} \mathrm{C}$ overnight. The resulting polymer $\mathbf{6}$, a pale-brown powder, was soluble in DMF and DMSO. Yield: $96 \% ; T_{g 1}=198^{\circ} \mathrm{C} ; T_{g 2}=227^{\circ} \mathrm{C} ; T_{d 1}=272^{\circ} \mathrm{C}$ (sulfonic group loss) $T_{d 2}=458^{\circ} \mathrm{C}$ (main chain decomposition); ${ }^{1} \mathrm{H}$ NMR $\left(300 \mathrm{MHz}, \mathrm{DMF}-d_{7}\right): \delta(\mathrm{ppm})=7.81(2 \mathrm{H}, \mathrm{m}), 7.53-7.34(5 \mathrm{H}, \mathrm{m}), 7.27(2 \mathrm{H}, \mathrm{m})$, $3.65(2 \mathrm{H}, \mathrm{s}), 3.09,2.24,1.90,1.65,1.28 ;{ }^{13} \mathrm{C}$ NMR $\left(75 \mathrm{MHZ}, \mathrm{DMSO}-d_{6}\right): \delta(\mathrm{ppm})=178.2(\mathrm{C}=\mathrm{O}), 177.9(\mathrm{C}=$ O), 127.9 (C-O), 114.9, $107.5(\mathrm{C}-\mathrm{N}), 51.6 ;{ }^{19} \mathrm{~F}$ NMR (300 MHz, DMF- $d_{7}$, ref. TFA $\left.[-77 \mathrm{ppm}]\right): \delta(\mathrm{ppm})=$ $-141.9,-142.9,-150.0,-153.1,-160.4$; FT-IR (thin film, $\left.\mathrm{cm}^{-1}\right)$ : 3420, 2923 (C-H asym str), 2854 (C-H sym str), $1703(\mathrm{C}=\mathrm{O}), 1698(\mathrm{C}=\mathrm{O}), 1682,1505,1492,1359,1291(\mathrm{C}-\mathrm{F}), 1165\left(-\mathrm{SO}_{3} \mathrm{H}\right.$, asym str), 1124, 1033 (- $\mathrm{SO}_{3} \mathrm{H}$, sym str), 1008, 987, 742, 689, 608 .

\section{Results and Discussion}

Monomers 2a and $\mathbf{2 b}$ were prepared in high yields according to literature [8] [9]. 2,3,4,5,6-Pentafluoroaniline and aniline reacted with NDA to the corresponding amic acids which were cyclized to imide using acetic anhydride as dehydrating agent (Scheme 1). ${ }^{1} \mathrm{H},{ }^{13} \mathrm{C}$ and ${ }^{19} \mathrm{~F}$ NMR spectra as well as elemental analysis confirmed monomers structure and purity.

The high molecular weight copolymers were synthesized via ROMP using bis(tricyclohexylphosphine) benzylidene ruthenium(IV) dichloride (I) and tricyclohexylphosphine [1,3-bis(2,4,6-trimethylphenyl)-4,5-dihydroimidazol-2-ylidene] [benzylidene] ruthenium dichloride (II) (Scheme 2). Table 1 summarizes the results of the high conversion copolymerizations of $\mathbf{2 a}$ with $\mathbf{2 b}$. It is observed that catalyst II produced random high molecular weight copolymers in the early minutes of reaction in high yield at room temperature with almost complete incorporation of 2a in the copolymer (Entry 1). On the contrary, catalyst I was not able to incorporate monomer 2a in copolymer in the same time even at $45^{\circ} \mathrm{C}$ (Entry 3) and more reaction time was needed for the incorporation of $2 \mathrm{a}$ to take place and it could be detected by ${ }^{1} \mathrm{H}$ NMR (Entries 4 and 5). In fact, complete incorpo-
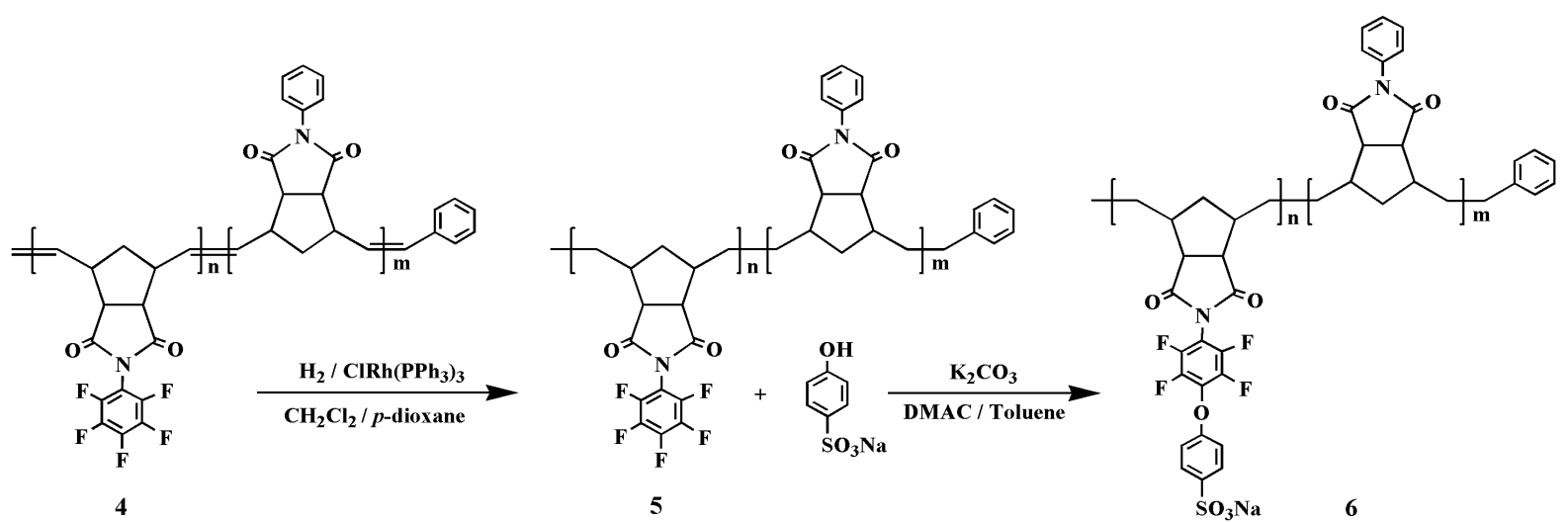

Scheme 3. Hydrogenation and further sulfonation of polynorbornene based copolymers bearing pentafluorophenyl moieties. 
Table 1. General conditions for copolymerization of monomer $\mathbf{2 a .}$

\begin{tabular}{|c|c|c|c|c|c|c|c|c|c|c|}
\hline Entry & Comonomer & Fashion & Catalyst $^{\mathrm{a}}$ & $\begin{array}{c}{\left[\mathrm{M}_{\mathrm{o}}\right]} \\
(\mathrm{mol} / \mathrm{L})\end{array}$ & $\begin{array}{c}\text { Temperature } \\
\left({ }^{\circ} \mathrm{C}\right)\end{array}$ & $\begin{array}{l}\text { Time } \\
(\mathrm{min})\end{array}$ & $\begin{array}{c}\text { Incorporation of } \\
2 \mathbf{a} \text { in copolymer } \\
(\%)^{\mathrm{b}}\end{array}$ & $\begin{array}{l}\text { Yield } \\
(\%)^{c}\end{array}$ & $\begin{array}{c}\mathrm{M}_{\mathrm{n}} \\
\times 10^{-5 \mathrm{f}}\end{array}$ & $M W D^{f}$ \\
\hline 1 & $2 b$ & Random & II & 1.0 & 25 & 5 & 42 & 91 & 2.45 & 1.26 \\
\hline 2 & $2 \mathrm{~b}$ & Random & II & 0.5 & 25 & 240 & 44 & 97 & 2.79 & 1.38 \\
\hline 3 & $2 \mathrm{~b}$ & Random & I & 0.7 & 45 & 5 & --- & 14 & 0.35 & 1.24 \\
\hline 4 & $2 b$ & Random & I & 0.7 & 45 & 15 & 30 & 65 & 1.53 & 1.17 \\
\hline 5 & $2 b$ & Random & I & 0.7 & 45 & 60 & 39 & 81 & 2.20 & 1.19 \\
\hline 6 & $2 b$ & Random & I & 0.7 & 65 & 120 & 48 & 97 & 2.85 & 1.22 \\
\hline 7 & $2 b$ & Block & I & 0.7 & 65 & $\begin{array}{l}20^{\mathrm{d}} \\
40^{\mathrm{e}}\end{array}$ & 32 & 84 & 2.60 & 1.15 \\
\hline 8 & $2 \mathrm{~b}$ & Block & I & 0.7 & 65 & $\begin{array}{l}20^{\mathrm{d}} \\
60^{\mathrm{e}}\end{array}$ & 41 & 88 & 2.73 & 1.16 \\
\hline 9 & $2 \mathrm{~b}$ & Block & I & 0.7 & 65 & $\begin{array}{l}20^{\mathrm{d}} \\
80^{\mathrm{e}}\end{array}$ & 48 & 96 & 2.80 & 1.20 \\
\hline
\end{tabular}

${ }^{\mathrm{a}}$ Molar ratio of monomer to catalyst $=1000,1,2$-Dichloroethane as solvent, Mol\% of 2a in the feed $=50$; ${ }^{\mathrm{b}}$ Determined by ${ }^{1} \mathrm{H}$ NMR; ${ }^{\mathrm{c}} \mathrm{Methanol}$ insoluble polymer; ${ }^{\mathrm{d}}$ Reaction time for monomer $\mathbf{2 b}$; ${ }^{\mathrm{e}}$ Reaction time for monomer $\mathbf{2} \mathbf{a}$; ${ }^{\mathrm{f}} \mathrm{GPC}$ analysis in tetrahydrofuran with polystyrene calibration standards.

ration of monomer $\mathbf{2 a}$ in copolymer, in high yield and using catalyst $\mathbf{I}$, was only achieved by increasing temperature to $65{ }^{\circ} \mathrm{C}$ (Entry 6 ). Block copolymers of $\mathbf{2 a}$ with $\mathbf{2 b}$ were synthesized in high yields using catalyst $\mathbf{I}$ (Entries 7-9). In the first case, the copolymerizations were conducted at $65^{\circ} \mathrm{C}$ and the monomer $\mathbf{2 b}$ was added initially polymerizing completely within $0.33 \mathrm{~h}$ (Entries 7-9). Immediately, monomer 2a was added to the reaction and complete incorporation of $\mathbf{2 a}$ in copolymer was detected after $1.33 \mathrm{~h}$ of being added to the growing polymer (Entry 9). Figure 1 shows the thermomechanical analysis performed on the random and block copolymers synthesized. As expected, a single transition is observed, at $205^{\circ} \mathrm{C}$, and interpreted as the glass transition temperature, $T_{g}$, of the random copolymer 3 whereas two transitions are observed for the block copolymer 4 , at $170^{\circ} \mathrm{C}$ and $224^{\circ} \mathrm{C}$, and attributed to the corresponding $T_{g}$ of $\mathbf{2 a}$ and $\mathbf{2 b}$ homopolymer regions, respectively. The thermo-oxidative stabilities of block copolymer 4 were enhanced by quantitative hydrogenation according to the methodology previously reported for this kind of polymers (Scheme 3 ) [10].

Figure 2 shows the X-ray diffraction patterns of the as cast random copolymer 3 as well as block copolymer 4 films.

Polymeric ionomer was synthesized by reaction of hydrogenated copolymer $\mathbf{5}$ with sodium 4-hydroxybenzenesulfonate dehydrate (Scheme 3). Ionomer films were cast from sulfonated copolymer solutions in DMF and DMSO, respectively. The films were quite flexible when fully hydrated and became somewhat brittle as they dried out. The substitution reaction was monitored by ${ }^{19} \mathrm{~F}$ NMR and ${ }^{1} \mathrm{H}$ NMR spectroscopy and the degree of sulfonation was controlled both by the nucleophilic agent amount and the time of reaction. According to Figure 3 , it is appreciated that as the pentafluorophenyl moiety is sulfonated, the signal corresponding to the fluorine atom in meta position of unsulfonated copolymer $5(\mathrm{~b},-160.2 \mathrm{ppm})$ becomes weak and a new meta signal corresponding to those pentafluorophenyl moieties which have already been sulfonated (6) become to grow (d, $-153.1 \mathrm{ppm})$ until a unique meta signal is observed at complete sulfonation of copolymer $5(\mathrm{~d},-153.1 \mathrm{ppm})$.

The signal corresponding to the fluorine atom in para position $(\mathrm{c},-150.1 \mathrm{ppm})$ decreases until its complete disappearance when a fully sulfonated copolymer is obtained. From this analysis we conclude that only the carbon in para position has undergone the nucleophilic aromatic substitution. In addition, FT-IR allowed us to confirm the introduction of sulfonate groups in the copolymers by observing the characteristic bands around 1033 and $1165 \mathrm{~cm}^{-1}$ assigned to symetric and asymmetric stretching of sulfonate groups.

\section{Conclusion}

The random and block high molecular weight copolymers of $\mathbf{2 a}$ with $\mathbf{2 b}$ using ruthenium alkylidene catalysts 


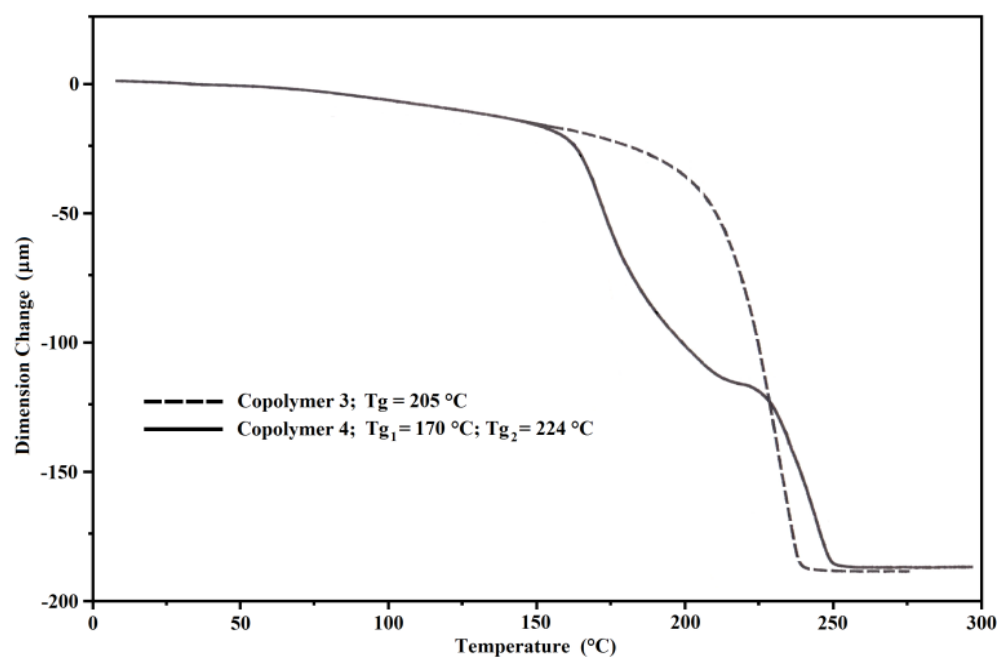

Figure 1. Thermomechanical analysis of random copolymer $\mathbf{3}$ and block copolymer 4.

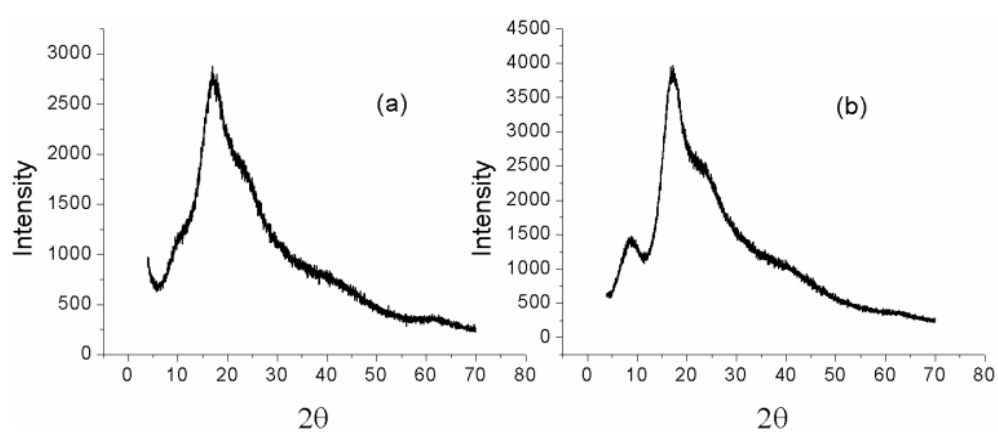

Figure 2. X-Ray diffraction patterns of (a) random copolymer 3 and (b) block copolymer 4.

b)
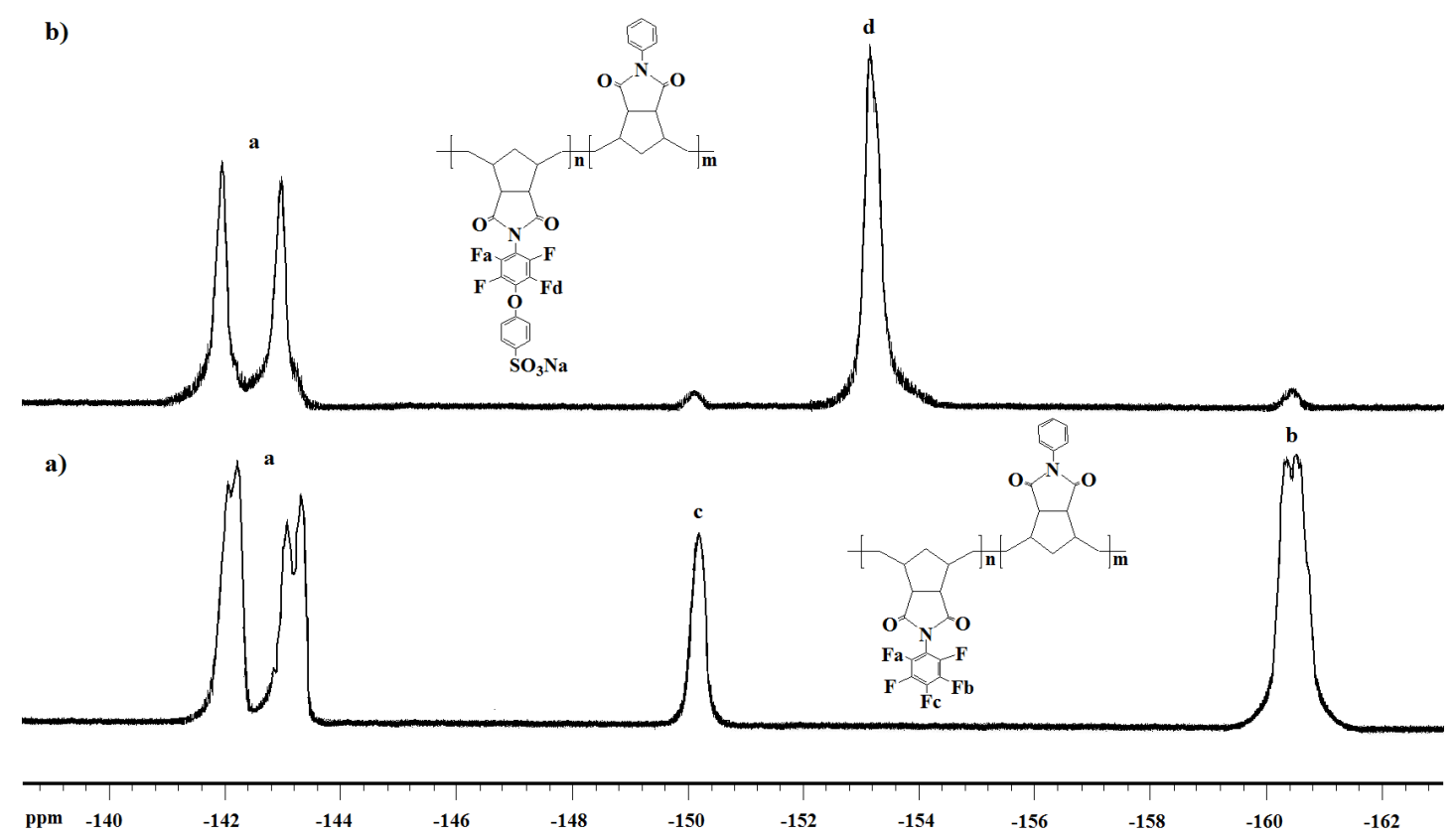

Figure 3. ${ }^{19} \mathrm{~F}$ NMR spectra of a) non-sulfonated copolymer $\mathbf{5}$ and b) sulfonated copolymer $\mathbf{6}$. 
were synthesized. The main chains were hydrogenated and the perfluoroaromatic moieties were further sulfonated quantitatively to yield thermally enhanced film forming new polymeric ionomers.

\section{References}

[1] Blackmore, P.M. and Feast, W.J. (1988) Stereoregular Fluoropolymers: 6. The Ring-Opening Polymerization of NPentafluorophenylbicyclo[2.2.1] hept-5-ene-2,3-dicarboximide. Journal of Fluorine Chemistry, 40, 331-347. http://dx.doi.org/10.1016/S0022-1139(00)83072-9

[2] Dragutan, V. and Streck, R. (2000) Catalytic Polymerization of Cycloolefins. Elsevier, Amsterdam.

[3] Vargas, J., Martínez, A., Santiago, A.A., Tlenkopatchev, M.A., Gaviño, R. and Aguilar-Vega, M.J. (2009) The Effect of Fluorine Atoms on Gas Transport Properties of New Polynorbornene Dicarboximides. Journal of Fluorine Chemistry, 130, 162-168. http://dx.doi.org/10.1016/j.jfluchem.2008.09.011

[4] Vargas, J., Martínez, A., Santiago, A.A., Tlenkopatchev, M.A. and Aguilar-Vega, M. (2007) Synthesis and Gas Permeability of New Polynorbornene Dicarboximide with Fluorine Pendant Groups. Polymer, 48, 6546-6553. http://dx.doi.org/10.1016/j.polymer.2007.08.064

[5] Ghassemi, H., McGrath, J.E. and Zawodzinski Jr., T.A. (2006) Multiblock Sulfonated-Fluorinated Poly(arylene ether)s for a Proton Exchange Membrane Fuel Cell. Polymer, 47, 4132-4139. http://dx.doi.org/10.1016/j.polymer.2006.02.038

[6] Vargas, J., Santiago, A.A., Tlenkopatchev, M.A., Gaviño, R., Laguna, M.F., López-González, M.M. and Riande, E. (2007) Gas Transport and Ionic Transport in Membranes Based on Polynorbornenes with Functionalized Imide Side Groups. Macromolecules, 40, 563-570. http://dx.doi.org/10.1021/ma062522q

[7] Vargas, J., Santiago, A.A., Tlenkopatchev, M.A., Gaviño, R., Laguna, M.F., López-González, M.M. and Riande, E. (2007) Adv. In Tech. of Mat. and Mat. Proc. J., 9, 135-140.

[8] Contreras, A.P., Cerda, A.M. and Tlenkopatchev, M.A. (2002) Synthesis of High- $T_{g}$ Polymers by Ring-Opening Metathesis Polymerization of $\mathrm{N}$-Cycloalkylnorbornene Dicarboximide. Macromolecular Chemistry and Physics, 203, 1811-1818. http://dx.doi.org/10.1002/1521-3935(200208)203:12<1811::AID-MACP1811>3.0.CO;2-J

[9] Asrar, J. (1992) Metathesis Polymerization of N-Phenylnorbornenedicarboximide. Macromolecules, 25, $5150-5156$. http://dx.doi.org/10.1021/ma00046a006

[10] Vargas, J., Santiago, A.A., Gaviño, R., Cerda, A.M. and Tlenkopatchev, M.A. (2007) Synthesis and Ring-Opening Metathesis Polymerization (ROMP) of New $N$-Fluoro-Phenylnorbornene Dicarboximides by 2nd Generation Ruthenium Alkylidene Catalysts. Express Polymer Letters, 1, 274- 282. http://dx.doi.org/10.3144/expresspolymlett.2007.40

[11] Woodward, A.E. (1995) Understanding Polymer Morphology. Hanser Publishers, New York.

[12] Santiago, A.A., Vargas, J., Cruz-Gomez, J., Tlenkopatchev, M.A., Gaviño, R., Laguna, M.F., López-González, M.M. and Riande, E. (2011) Synthesis and Ionic Transport of Sulfonated Ring-Opened Polynorbornene Based Copolymers. Polymer, 52, 4208-4221. http://dx.doi.org/10.1016/j.polymer.2011.07.030 
Scientific Research Publishing (SCIRP) is one of the largest Open Access journal publishers. It is currently publishing more than 200 open access, online, peer-reviewed journals covering a wide range of academic disciplines. SCIRP serves the worldwide academic communities and contributes to the progress and application of science with its publication.

Other selected journals from SCIRP are listed as below. Submit your manuscript to us via either submit@scirp.org or Online Submission Portal.
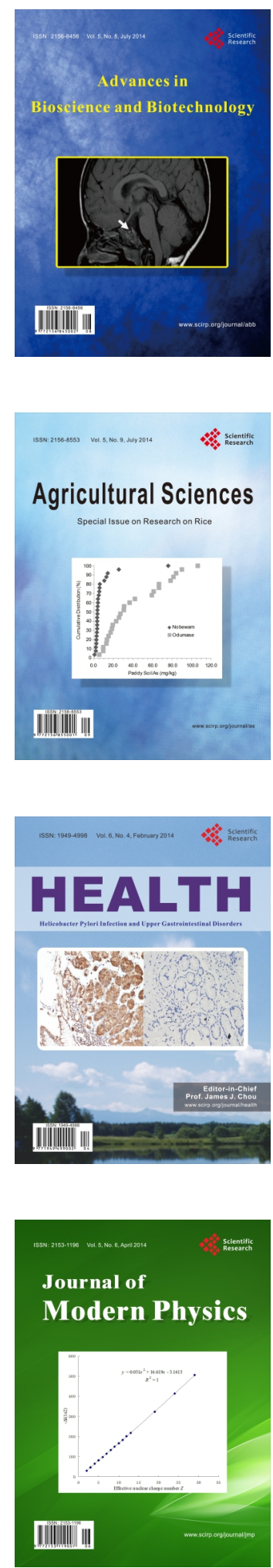
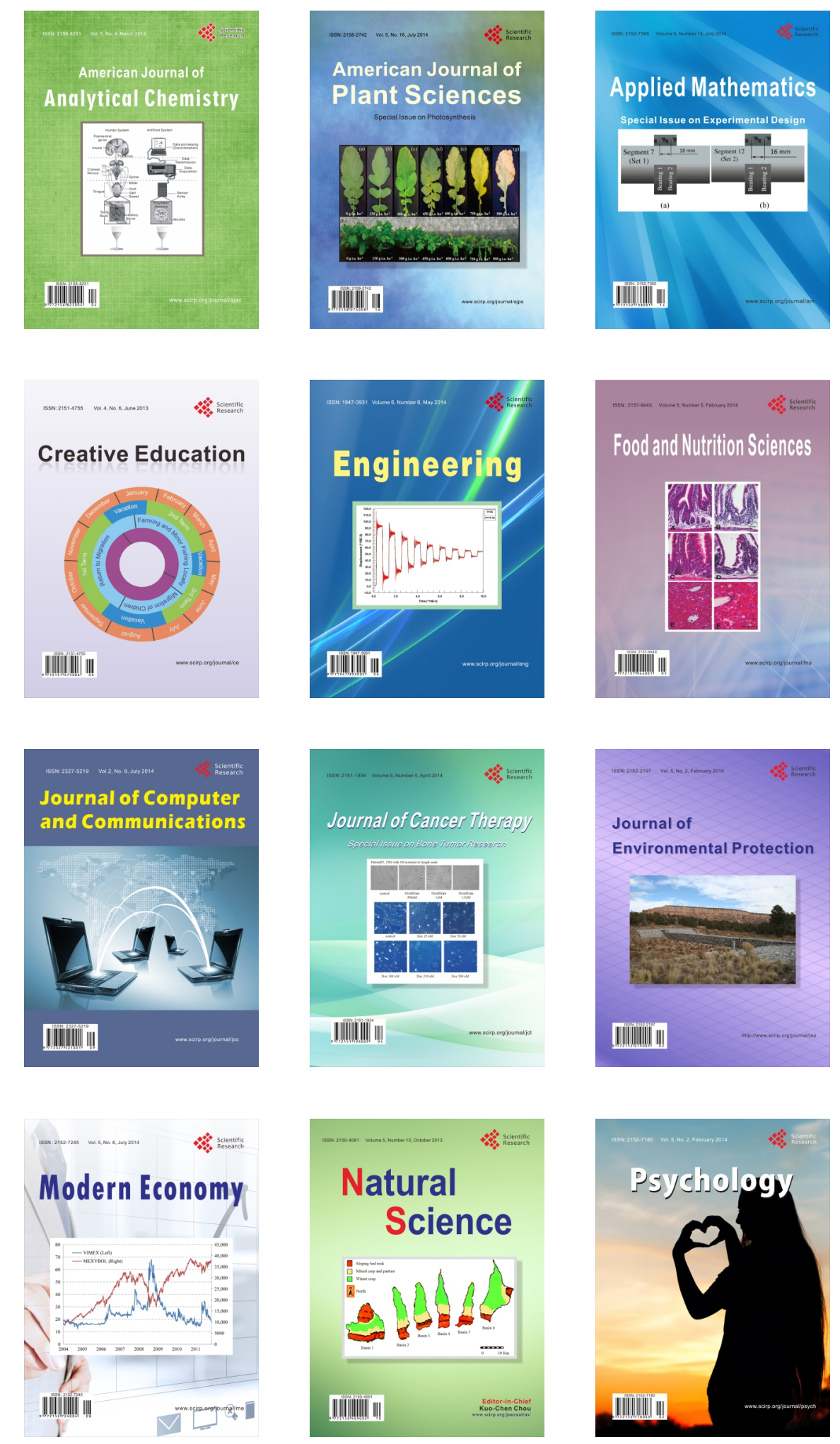